\title{
Investigation of the Relationship Between Class Teachers' Levels of Mathematical Thinking and Mathematics Teaching Anxiety in Terms of Different Variables
}

\author{
Coşkun Küçüktepe ${ }^{1} \&$ Sevgi Balkan² \\ ${ }^{1}$ Hasan Ali Yücel Faculty of Education, Istanbul University-Cerrahpasa, Istanbul, Turkey \\ ${ }^{2}$ Institute of Graduate Studies, Istanbul University-Cerrahpasa, Istanbul, Turkey \\ Correspondence: Coşkun Küçüktepe, Hasan Ali Yücel Faculty of Education, Istanbul University-Cerrahpasa, \\ Istanbul, Turkey. E-mail: coskun.kucuktepe@istanbul.edu.tr
}

Received: February 24, 2021

doi:10.5539/ies.v14n7p91

\author{
Accepted: March 27, 2021 \\ Online Published: June 27, 2021 \\ URL: https://doi.org/10.5539/ies.v14n7p91
}

\begin{abstract}
The current study aimed to investigate the relationship between class teachers' level of mathematical thinking and level of anxiety about mathematics teaching in terms of different variables. To this end, the correlational and causal comparative method, one of the qualitative research methods, was used in the study. The study group of the current research is comprised of 509 class teachers working in state primary schools in the city of İstanbul in the 2019-2020 school year. As the data collection tools, the "Class Teachers' Mathematical Thinking Scale" and the "Mathematics Teaching Anxiety Scale" were used. In the analysis of the data obtained from the scales, descriptive and parametric analyses (t-test and ANOVA) and Pearson Product-Moment Correlation were used. A low and negative correlation was found between the class teachers' levels of mathematical thinking and mathematics teaching anxiety. Moreover, the class teachers' levels of mathematical thinking and mathematics teaching anxiety were found to be varying significantly depending on gender. In addition, the class teachers' levels of mathematical thinking and mathematics teaching anxiety were also found to be varying depending on the type of high school graduated and the length of service in the profession.
\end{abstract}

Keywords: class teachers, mathematical thinking, mathematics teaching, anxiety

\section{Introduction}

Human beings have interacted with nature through their ability to adapt, and this struggle has taken place in a very long process that has enabled them to survive up to now. Our power of perception, enriched with mathematics, has enabled us to go beyond the struggle with nature and to dominate as we have been able to live in harmony in nature. This harmony has been written in mathematics and perceived with mathematics in mind (Sertöz, 2000). Mathematics is a language of thinking (Umay, 1992), but it is necessary to distinguish between mathematics and mathematical thinking. Knowledge is needed to think, but mere knowledge is not enough (Yıldırım, 1996). For mathematical thinking, personal experience, creativity, analysis, synthesis, the ability to predict, and a different perspective are required.

Mathematical thinking has set reaching the truth as its main goal. It is basically in the same position with every day and scientific thinking. The concept of truth requires proof in mathematics and logic, whereas for everyday and scientific thinking, truth is dependent on experimental or observational data (Yıldırım, 1996). Mathematical thinking is a process that explicitly or indirectly supports the solution of a problem in a situation and during which mathematical techniques, concepts and relationships are used and applied (Henderson, 2002). This process plays an important role in leading the problem to a solution, and the emerging result is added to the experiences and improves the real-life connection between thinking and practice (Devlin, 2000). By accepting each problem solving activity as a practice, the level of consciousness in individuals can be increased with the important role that mathematics can play (Henderson, 2002). Various approaches based on five important assumptions have been proposed in the development of mathematical thinking:

1) It is possible to think mathematically.

2) Mathematical thinking can be improved by addressing questions and practicing through reflection. 
3) Mathematical thinking can be provoked by situations of surprise, tension, and conflict.

4) Mathematical thinking can be supported by an atmosphere of questioning, challenge and reflection.

5) Maintaining mathematical thinking can help us to increase our understanding of the world (Mason, Burton and Stacey, 2010).

Mathematics has an important place in life both as a science and a subject taught at schools. It is known that mathematics, which has become one of the cornerstones of the developments in science and technology over time, has an important place. This situation made it necessary to change the traditional understanding of mathematics teaching and to move away from an understanding imposed by the teacher, in which the student is perceived as a passive receiver ready to acquire independent pieces of information presented by the teacher to be competent enough to answer questions which have known and pre-determined answers (Olkun \& Toluk, 2018).

Today, mathematics is an activity that has a high intellectual value in itself, stimulating, nurturing and developing students' interests in exploration and creation (Yıldırım, 1996). This new dimension gained by mathematics manifests itself in curriculums. In this regard, in line with the General Objectives and Basic Principles specified in the Basic Law of National Education No.1739 in Turkey, it is stated in the Mathematics Curriculum, for the accomplishment of some objectives to be achieved by students, it is not enough for students to develop their mathematical literacy skills but to use them effectively in practice.

In the process of problem solving, in addition to expressing their own ideas and reasoning, students are expected to see the existing deficiencies and/or gaps in others' mathematical reasoning. It is aimed for students to be learners who have developed their metacognitive knowledge and skills, can manage their own learning processes consciously, and develop a positive attitude and take a self-confident approach to the problems they encounter (MEB, 2018). In general, it is understood that the objectives are different from the ones handled by traditional approaches, affective domains are also addressed in addition to cognitive domains, and the sub-steps required to gain mathematical thinking skills are included in the curriculum.

While some of the main objectives of math teaching are defined by Ersoy (1998) as improving students' logical thinking skills, students' ability to evaluate the available data in solving the problems they encounter, developing their mental independence and creativity skills and teaching them to be respectful to different thoughts, they are defined by Altun (2018) as a way of thinking including the ability of using mathematical knowledge and skills in the solutions of problems in the face of real life problems.

On the basis of the emphasis put on these general objectives, it becomes clear that it is necessary to learn, teach and develop ways of mathematical thinking in math classes.

In our country, both teachers and parents attach a special importance to student success in mathematics. General school achievement of students can often be seen as equivalent to their success in mathematics. This can cause both teachers and students to develop negative emotions against mathematics teaching and learning (Baloğlu, 2001; Sar1, 2014). While the teacher is teaching a math subject and the student is learning it, they can both be anxious about making mistake.

Experiencing negative emotions at early ages in mathematics lessons may cause anxiety to continue increasing in the following years if no precautions are taken. Many people find even the word math terrifying, exaggerating their own inadequacy about math (Hardy, 2019). Teachers should avoid giving unnecessary and long homework, give sufficient time for students to complete the tasks they are working on, and respect the solutions that students reach in different ways in order to prevent negative experiences of students. Students should not be limited to a single solution, and discussions on subjects of mathematics should be included in the classroom.

Teachers should take slow learners into account when organizing their classroom activities (Altun, 2018). On the other hand, students may develop the misconception that they can learn by memorizing the subjects they encounter in mathematics. As memorized subjects are doomed to be forgotten in a short time, this misconception will lead to undesirable situations and will prevent students from recognizing that mathematics progresses in an orderly and harmonious manner, with certain aesthetics and beauty (Pesen, 2019). Lack or absence of such recognitions on the part of students may create pressure on teachers and make them feel anxious about failing in covering the subjects as required in the curriculum and in transmitting enough knowledge to students.

In mathematics teaching, teachers' mathematical thinking levels are expected to be high and their anxiety levels are expected to be low because one of the factors that develop mathematical thinking is low anxiety level (Hudson, Henderson, \& Hudson, 2015). 


\subsection{Problem}

Is there a statistically significant correlation between class teachers' levels of mathematical thinking and mathematics teaching anxiety in terms of different variables?

\subsection{Purpose of the Study}

The purpose of the current study is to investigate whether there is a significant correlation between class teachers' levels of mathematical thinking and mathematics teaching anxiety and whether their levels of mathematical thinking and mathematics teaching anxiety vary significantly depending on gender, the high school graduated and length of service. To this end, answers to the following questions were sought;

- Is there a significant correlation between the class teachers' levels of mathematical thinking and mathematics teaching anxiety?

- Do the class teachers' levels of mathematical thinking and mathematics teaching anxiety vary significantly depending on gender?

- Do the class teachers' levels of mathematical thinking and mathematics teaching anxiety vary significantly depending on the type of high school graduated?

- Do the class teachers' levels of mathematical thinking and mathematics teaching anxiety vary significantly depending on length of service?

\subsection{Assumptions}

The teachers whose opinions were sought within the context of the current study sincerely responded to the items in the scales given by the researcher.

\subsection{Limitations}

The current study is limited to the study group.

\section{Method}

The current study employed the relational research method, one of the qualitative research methods. In relational research, correlational and causal comparison is one of the widely used research methods (Büyüköztürk, Akgün, Çakmak, Demirel, \& Karadeniz, 2019). In the current study, a correlational and causal comparison was also made.

\subsection{Study Group}

The study group of the current study conducted to determine the class teachers' levels of mathematical thinking and mathematics teaching anxiety in terms of different variables is comprised of 509 class teachers working in state primary schools in the city of İstanbul in the 2019-2020 school year. Demographic information about the participants is given in Table 1.

Table 1. Demographic information about the participants

\begin{tabular}{cccc}
\hline Variable & Level & $f$ & $\%$ \\
\hline \multirow{3}{*}{ Gender } & Female & 318 & 62.5 \\
\cline { 2 - 4 } & Male & 191 & 37.5 \\
\hline \multirow{3}{*}{ Type of High School } & General High School & 261 & 51.3 \\
\cline { 2 - 4 } & Anatolian High School & 166 & 32.6 \\
\cline { 2 - 4 } & Vocational High School & 82 & 16.1 \\
\hline \multirow{3}{*}{ Length of Service } & 1 and 10 years & 149 & 29.3 \\
\cline { 2 - 4 } & 11 and 20 years & 226 & 44.4 \\
\cline { 2 - 4 } & 21 years and more & 134 & 26.3 \\
\hline
\end{tabular}

In Table 1, frequencies and percentages regarding the participating teachers' gender, type of high school graduated and length of service are presented. Of the participating teachers, $191(37.5 \%)$ are males and $318(62.5 \%)$ are females. The highest number of teachers was found to be the graduates of General High School, followed by the graduates of Anatolian High School and the graduates of Vocational High Schools. When the length of service in the profession was examined, it was found that the highest number of the teachers has the professional experience of $11-20$ years and more than $73.7 \%$ of them have been working for $1-20$ years. 


\subsection{Data Collection Tools}

The data collection tools used in the current study is the "Mathematical Thinking Scale" developed by Ersoy and Başer (2013) and the "Mathematics Teaching Anxiety Scale" developed by Sarı (2014). The reliability of the Mathematical Thinking Scale was calculated to be 0.78 by Ersoy and Başer (2013). The reliability of the Mathematics Teaching Anxiety Scale was calculated to be 0.89 by Sarı (2014).

In the current study, the reliability studies of the scale were conducted again. To this end, Cronbach Alpha coefficient was calculated for the both scales and the reliability of the Mathematical Thinking Scale was found to be 0.84 and that of the Mathematics Teaching Anxiety Scale was found to be 0.92 . These results were found to be adequate for the reliability of the scales.

The Mathematical Thinking Scale consists of 20 positive and 5 negative; thus, a total of 25 items. The 5 negative items are scored by reversely coding them. The highest score to be taken from the scale is 125 while the lowest score is 25 . Higher scores taken from the scale indicate increasing level of mathematical thinking.

The Mathematics Teaching Anxiety Scale consists of 23 items and the highest score to be taken from the scale is 115 while the lowest score is 23 . There is no reverse coded item in the scale. Higher scores taken from the scale indicate increasing level of anxiety.

\subsection{Data Collection}

The "Mathematical Thinking Scale" developed by Ersoy and Başer (2013) and the "Mathematics Teaching Anxiety Scale" developed by Sarı (2014) were administered to 509 class teachers working in state primary schools in the city of İstanbul. The researcher went to these schools in person and after making the necessary explanations about the scales, she administered the scales to the participating teachers. Completion of the scales lasted for 15 minutes on average.

\subsection{Data Analysis}

The data collected through the scales were appropriately classified and then transferred to computer environment and analysed by using SPSS 20.0 program package. In the analysis of the data, first the data about the demographic variables were analyzed and then the data obtained from the scales were analyzed.

For the demographic variables (age, the type of high school graduated, length of service) of the participants, frequencies, percentages, means and standard deviations were calculated. In order to determine whether the scores taken by the teachers from the scales vary significantly depending on gender, $t$-test was conducted and in order to determine whether their scores vary significantly depending on the types of high school graduated and length of service, one-way variance analysis (ANOVA) was conducted.

In order to determine whether there is a significant correlation between the scores taken from the scales, Pearson Product-Moment Correlation analysis was run. The results of the analyses are explained in detail in the findings section below.

\section{Findings}

In this section, the findings obtained for the research problem are presented in tables. Before starting the analysis of the data obtained from the "Mathematical Thinking Scale" and the "Mathematics Teaching Anxiety Scale", it was checked whether the data showed a normal distribution and after they were found to show a normal distribution, their analysis was initiated. The mean scores taken by the participants from the mathematical thinking and mathematics teaching anxiety scales are given in Table 2 .

Table 2. Mean scores taken by the participants from the mathematical thinking and mathematics teaching anxiety scales

\begin{tabular}{lccc}
\hline Scales & $\mathrm{N}$ & $\bar{X}$ & $\mathrm{SD}$ \\
\hline Mathematical Thinking Scale & 509 & 96.32 & 9.68 \\
Mathematics Teaching Anxiety Scale & 509 & 51.28 & 14.83 \\
\hline
\end{tabular}

When the mean score taken by the participating teachers from the Mathematical Thinking Scale (93.32) is considered, it can be said that their level of mathematical thinking is considerably high and when their mean score taken from the Mathematics Teaching Anxiety Scale (51.28) is considered, it can be said that their level of anxiety about mathematics teaching is low. The results of the independent samples t-test conducted to determine whether the participating teachers' mathematical thinking scores vary significantly depending on gender are presented in 
Table 3.

Table 3. Results of the independent samples t-test conducted to determine whether the participants' mathematical thinking scores vary significantly depending on gender

\begin{tabular}{ccccccc}
\hline Gender & $\mathrm{N}$ & $\bar{X}$ & $\mathrm{SD}$ & $\mathrm{df}$ & $\mathrm{t}$ & $\mathrm{p}$ \\
\hline Female & 318 & 97.3805 & 8.73135 & & & \\
Male & 191 & 94.5707 & 10.88330 & & -3.030 & $.003^{*}$ \\
\hline
\end{tabular}

$* \mathrm{p}<0.05$.

As can be seen in Table 3, the class teachers' mathematical thinking scores vary significantly depending on gender

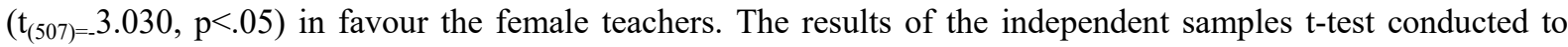
determine whether the participating teachers' mathematics teaching anxiety scores vary significantly depending on gender are given in Table 4.

Table 4. Results of the independent samples t-test conducted to determine whether the participants' mathematics teaching anxiety scores vary significantly depending on gender

\begin{tabular}{ccccccc}
\hline Gender & $\mathrm{N}$ & $\bar{X}$ & $\mathrm{SD}$ & $\mathrm{df}$ & $\mathrm{t}$ & $\mathrm{p}$ \\
\hline Female & 318 & 49.2421 & 13.07131 & \multirow{2}{*}{507} & \multirow{2}{*}{3.830} & $.000^{*}$ \\
Male & 191 & 54.6963 & 19.87577 & & & \\
\hline
\end{tabular}

$* \mathrm{p}<0.05$.

As can be seen in Table 4, the class teachers' mathematics anxiety scores vary significantly depending on gender $\left(\mathrm{t}_{(507)}=3.830, \mathrm{p}<.05\right)$ in favour the female teachers; that is, the mean anxiety score of the female teachers is significantly lower than that of the male teachers. The results of the analysis conducted to determine the mean mathematical thinking scores of the teachers having graduated from different types of high schools are given in Table 5 .

Table 5. Mean mathematical thinking scores of the teachers having graduated from different types of high schools

\begin{tabular}{cccc}
\hline Type of High School Graduated & $\mathrm{N}$ & $\bar{X}$ & SD \\
\hline General High School & 261 & 96.4253 & 10.13140 \\
Anatolian High School & 166 & 97.5542 & 7.88747 \\
Vocational High School & 82 & 93.5244 & 10.97947 \\
Total & 509 & & \\
\hline
\end{tabular}

As can be seen in Table 5, the mean mathematical thinking scores of the teachers having graduated from General High Schools and Anatolian High Schools are close to each other but higher than that of the teachers having graduated from Vocational High Schools. The results of the ANOVA test conducted to determine whether the teachers' mathematical thinking scores vary significantly depending on the type of high school graduated are given in Table 6.

Table 6. Results of ANOVA conducted to determine whether the teachers' mathematical thinking scores vary significantly depending on the type of high school graduated

\begin{tabular}{ccccccc}
\hline Source of the Variance & Sum of Squares & df & Mean Square & F & p & Significant Difference \\
\hline Between-Groups & 896.606 & 2 & 448.303 & & & \\
Within-Groups & 46717.256 & 506 & 92.327 & 4.856 & $.008^{*}$ & VHS $^{* *}-$ GHS $^{* *}$, \\
Total & 47613.862 & 508 & & & & VHS - AHS $^{* *}$ \\
\hline
\end{tabular}

$* \mathrm{p}<0.05 ; * * \overline{V H S}$, Vocational High School; GHS, General High School; AHS, Anatolian High School.

One-way Variance Analysis (ANOVA) was conducted to determine whether the participating teachers' 
mathematical thinking scores vary significantly depending on the type of high school graduated. As a result of the variance analysis, it was concluded that the teachers' mathematical thinking scores vary significantly depending on the type of high school graduated $\left[\mathrm{F}_{(2-506)}=4.856, \mathrm{p}<0.05\right]$ in Table 6 . In order to find the source of the difference, Tukey Test, one of the multiple comparison tests, was used and significant differences were found between Vocational High School $($ VHS) $=93.5244$ and General High School $($ GHS $)=96.4253$ and between Vocational High School (VHS) and Anatolian High School (AHS) $=97.5542$. The mean mathematical thinking score of the teachers having graduated from Vocational High Schools is significantly lower than those of the teachers having graduated from General High Schools and Anatolian High Schools. The results of the analysis conducted to determine the mean mathematics teaching anxiety scores of the teachers having graduated from different types of high schools are given in Table 7.

Table 7. Mean mathematics teaching anxiety scores of the teachers having graduated from different types of high school

\begin{tabular}{cccc}
\hline Type of High School Graduated & $\mathrm{N}$ & $\bar{X}$ & SD \\
\hline General High School & 261 & 50.4674 & 14.18409 \\
Anatolian High School & 166 & 51.9157 & 15.32612 \\
Vocational High School & 82 & 52.2888 & 15.85701 \\
Total & 509 & & \\
\hline
\end{tabular}

As can be seen in Table 7, the mean mathematics teaching anxiety scores of the class teachers having graduated from General High Schools, Anatolian High Schools and Vocational High Schools are close to each other. The results of the ANOVA test conducted to determine whether the teachers' mathematics teaching anxiety scores vary significantly depending on the type of high school graduated are given in Table 8 .

Table 8. Results of the ANOVA test conducted to determine whether the teachers' mathematics teaching anxiety scores vary significantly depending on the type of high school graduated

\begin{tabular}{cccccc}
\hline Source of the Variance & Sum of Squares & df & Mean Square & F & p \\
\hline Between-Groups & 389.729 & 2 & 194.865 & & \\
Within-Groups & 111432.817 & 506 & 220.223 & .885 & .413 \\
Total & 111822.456 & 508 & & & \\
\hline
\end{tabular}

One-way Variance Analysis (ANOVA) was conducted to determine whether the participating teachers' mathematics teaching anxiety scores vary significantly depending on the type of high school graduated. As a result of the variance analysis, it was concluded that the teachers' mathematics teaching anxiety scores do not vary significantly depending on the type of high school graduated. The results of the analysis conducted to determine the mean mathematical thinking scores of the teachers having different lengths of service are given in Table 9.

Table 9. Mean mathematical thinking scores of the teachers having different lengths of service

\begin{tabular}{cccc}
\hline Length of Service & $\mathrm{N}$ & $\bar{X}$ & $\mathrm{SD}$ \\
\hline 1 and 10 years & 149 & 90.6242 & 11.05910 \\
11 and 20 years & 226 & 96.6460 & 7.35684 \\
21 years and more & 134 & 102.1269 & 7.73569 \\
Total & 509 & & \\
\hline
\end{tabular}

As can be seen in Table 9, the mean mathematical thinking scores of the teachers having different lengths of service are different from each other. The results of the ANOVA test conducted to determine whether the teachers' mathematical thinking scores vary significantly depending on length of service are presented in Table 10. 
Table 10. Results of the ANOVA conducted to determine whether the teachers' mathematical thinking scores vary significantly depending on length of service

\begin{tabular}{ccccccc}
\hline Source of the Variance & Sum of Squares & df & Mean Square & $\mathrm{F}$ & $\mathrm{p}$ & Significant dif. \\
\hline Between-Groups & 9376.385 & 2 & 4688.192 & & & $\mathrm{G} 1^{* *}-\mathrm{G} 2^{* *}$, \\
Within-Groups & 38237.478 & 506 & 75.568 & 62.039 & $.000^{*}$ & $\mathrm{G} 1-\mathrm{G} 3^{* *}$, \\
Total & 47613.862 & 508 & & & & $\mathrm{G} 2-\mathrm{G} 3$ \\
\hline
\end{tabular}

${ }^{*} \mathrm{p}<0.05 ;{ }^{*} \mathrm{G} 1=1-10$ years; $\mathrm{G} 2=11-20$ years; $\mathrm{G} 3=21$ years and more.

One-way Variance Analysis (ANOVA) was conducted to determine whether the participating teachers' mathematical thinking scores vary significantly depending on length of service. As a result of the variance analysis, it was concluded that the teachers' mathematical thinking scores vary significantly depending on length of service $[\mathrm{F}(2-506)=62.039, \mathrm{p}<0.05]$. In order to determine the source of the difference, Tukey Test, one of the multiple comparison tests, was conducted and significant differences were found between G1 (1 - 10 years $)=$ 90.6242 and G2 $(11-20$ years $)=96.6460$, between G1 and G3 $(21$ years and more $)=102.1269$ and between G2 and G3. The mathematical thinking level of the teachers who have been teaching for 21 years and more is higher than those of the teachers who have been working for 1 and 10 years and 11 and 20 years. The mathematical thinking level of the teachers who have been teaching for 11 and 20 years is higher than that of the teachers who have been teaching for 1 and 10 years. The results of the analysis conducted to determine the mean mathematics teaching anxiety scores of the teachers having different lengths of service are given in Table 11.

Table 11. Mean mathematics teaching anxiety scores of the teachers having different lengths of service

\begin{tabular}{cccc}
\hline Length of Service & $\mathrm{N}$ & $\bar{X}$ & SD \\
\hline 1 and 10 years & 149 & 55.4832 & 14.37133 \\
11 and 20 years & 226 & 48.9292 & 14.47832 \\
21 years and more & 134 & 50.6045 & 15.05580 \\
Total & 509 & & \\
\hline
\end{tabular}

As can be seen in Table 11, the mean mathematics teaching anxiety scores of the teachers with different lengths of service are different from each other. The results of the ANOVA conducted to determine whether the teachers' mathematics teaching anxiety scores vary significantly depending on length of service are given in Table 12.

Table 12. Results of the ANOVA conducted to determine whether the teachers' mathematics teaching anxiety scores vary significantly depending on length of service

\begin{tabular}{ccccccc}
\hline Source of the Variance & Sum of Squares & df & Mean Square & F & p & Significant Dif. \\
\hline Between-Groups & 3942.434 & 2 & 1971.217 & & & G1** - G2**, \\
Within-Groups & 107880.113 & 506 & 213.202 & 9.246 & $.000^{*}$ & G1 - G3 ${ }^{* *}$ \\
Total & 111822.546 & 508 & & & & \\
\hline
\end{tabular}

$* \mathrm{p}<0.05 ; * * \mathrm{G} 1=1-10$ years; $\mathrm{G} 2=11-20$ years; $\mathrm{G} 3=20$ years and more.

One-way Variance Analysis (ANOVA) was conducted to determine whether the participating teachers' mathematics teaching anxiety scores vary significantly depending on length of service. As a result of the variance analysis, it was concluded that the teachers' mathematics teaching anxiety scores vary significantly depending on length of service $[\mathrm{F}(2-506)=9.246, \mathrm{p}<0.05]$. In order to find the source of the difference, Tukey Test, one of the multiple comparison tests, was conducted and significant differences were found between G1 (1 - 10 years $)=$ 55.4832 and G2 $(11-20$ years $)=48.9292$ and between G1 and G3 $(21$ years and more $)=50.6045$. The mathematics teaching anxiety level of the teachers who have been teaching for 1 and 10 years is higher than those of the teachers who have been teaching for 11 and 20 years and 21 years and more. The results of the Pearson Product-Moment Correlation analysis conducted to determine the correlation between the participating teachers' levels of mathematical thinking and mathematics teaching anxiety. 
Table 13. Results of the Pearson product-moment correlation analysis conducted to determine the correlation between the teachers' levels of mathematical thinking and mathematics teaching anxiety

\begin{tabular}{cccc}
\hline Variables & $\mathrm{N}$ & $\mathrm{r}$ & $\mathrm{p}$ \\
\hline $\begin{array}{c}\text { Mathematical Thinking Scale } \\
\text { Mathematics Teaching Anxiety Scale }\end{array}$ & 509 & $-.313^{* *}$ & $.000^{*}$ \\
\hline
\end{tabular}

$* \mathrm{p}<0.05$.

As can be seen in Table 13, there is a low, negative and significant correlation between the class teachers' levels of mathematical thinking and mathematics teaching anxiety $(\mathrm{r}=-.313, \mathrm{p}<0.01)$.

\section{Results and Discussion}

In the current study, it was attempted to explain the relationship between the class teachers' levels of mathematical thinking and mathematics teaching anxiety and whether their levels of mathematical thinking and mathematics teaching anxiety vary significantly depending on some variables. The teachers' mean mathematical thinking score was found to be higher than the mean score of the scale. The mathematical thinking levels of the teachers having graduated from General High Schools and Anatolian High Schools were found to be closer to each other but higher than that of the teachers having graduated from Vocational High Schools. Yorulmaz, Altıntaş, and Sidekli (2017) found that the mean mathematical thinking score of the class teachers is high and this was thought to be because they graduated from the science and mathematics departments of high schools. In other studies conducted on teachers and pre-service teachers, their mean mathematical thinking levels were also found be higher than the mean of the scales used (Ersoy \& Güner, 2014; Yorulmaz, Çokçalışkan, \& Çelik, 2018; Demirtaş, 2018), which supports the finding of the current study. Teachers' high level of mathematical thinking is believed to positively affect the mathematical thinking of their students (Taşdan, Çelik, \& Erduran, 2013; Demirtaş, 2018).

The mean mathematics teaching anxiety score of the participating teachers was found to be lower than the mean of the scale. The findings obtained in the studies conducted by Bekdemir (2007), Elmas (2010), Haciömeroğlu (2014) Ural (2015), Yorulmaz, Altıntaş, and Sidekli (2017), Deringöl (2018) also support this finding of the current study. In the current study, the participating class teachers' mathematical thinking and mathematics teaching anxiety scores were found to be varying significantly depending on gender. The female teachers' mean mathematical teaching score was found to be higher than that of the male teachers and the female teachers' mean mathematics teaching anxiety score was found to be lower than that of the male teachers. The participating class teachers' mean mathematical thinking and mathematics teaching anxiety scores were found to be varying significantly depending on length of service. The mathematical thinking level of the teachers who have been teaching for 1 and 10 years is lower than those of the teachers who have been teaching for 11 and 20 years and 21 and more years. The lowest mathematics teaching anxiety score was found for the teachers who have been teaching for 11 and 20 years.

A low, negative and significant correlation was found between the participating teachers' levels of mathematical thinking and mathematics teaching anxiety. In their study, Yorulmaz, Altıntaş, and Sidekli (2017) concluded that mathematical thinking has an effect on teachers' anxiety about learning mathematics.

In light of the findings of the current study, it can be suggested that more emphasis should be put on the development of programs to help pre-service teachers to keep their level of mathematical thinking high and their level of mathematics teaching anxiety low during their undergraduate education. And in-service training programs should be organized that can contribute to the development of mathematical thinking of active teachers.

\section{References}

Altun, M. (2018). Matematik öğretimi (21. Baskı). Bursa, Aktüel 16 BasımYayım Dağ.

Baloğlu, M. (2001). Matematik korkusunu yenmek. Kuram ve Uygulamada Eğitim Bilimleri Dergisi, 1(1), 59-76.

Bekdemir, M. (2007). İlköğretim matematik öğretmen adaylarındaki matematik kaygısının nedenleri ve azaltılması için öneriler (Erzincan Eğitim Fakültesi Örneği). Erzincan Eğitim Fakültesi Dergisi, 9(2), 131-144.

Büyüköztürk, Ş., Çakmak, E. K., Akgün, Ö. E., Karadeniz, Ş., \& Demirel, F. (2019). Bilimsel araştırma yöntemleri. Ankara: Pegem Akademi.

Demirtaş, B. (2018). Stnıf öğretmenlerinin yaratıcıllk fenomenine duyarlılı̆̆ ile matematiksel düşünme becerileri arasındaki ilişki. İstanbul: İstanbul Üniversitesi Cerrahpaşa, Lisansüstü Eğitim Enstitüsü, Temel 
Eğitim Anabilim Dalı, Sınıf Eğitimi Programı.

Deringöl, Y. (2018). Sınıf öğretmeni adaylarının matematik öğretimi kaygıları ve matematik öğretimi yeterliklerinin incelenmesi. Kuramsal Eğitimbilim Dergisi, 11(2), 261-278. https://doi.org/10.30831/akukeg.364483

Devlin, K. (2000). Finding your inner mathematician. Chronicle of Higher Education, 47(5), 5-6.

Elmas, S. H. (2010). Sinıf öğretmeni adaylarının matematik ögretmeye yönelik kaygı düzeyleri ve bu kaygıya neden olan faktörler (Yayınlanmamış yüksek lisans tezi). Afyon Kocatepe Üniversitesi, Sosyal Bilimler Enstitüsü, Afyon.

Ersoy, E., \& Başer, N. (2013). Matematiksel düşünme ölçeğinin geliştirilmesi. Kastamonu Eğitim Dergisi, 21(4), 1471-1486.

Ersoy, Y. (1998). Okullarda matematik öğretimi ve eğitimi: Ders öncesi hazırlıklar ve etkinlikler. Çağdaş Eğitim Dergisi, 244, 5-9.

Güner, P., \& Ersoy, E. (2014 ). Matematik öğretimi ve matematiksel düşünme. Eğitim ve Öğretim Araştırmaları Dergisi, 3(2), 102-112.

Haciömeroğlu, G. (2014). Elementary pre-service teachers' mathematics anxiety and mathematics teaching anxiety. International Journal for Mathematics Teaching and Learning. Retrieved from http://www.cimt.org.uk/journal/haciomeroglu.pdf

Hardy, G. H. (2019). Bir Matematikçinin Savunması (23. Basım). İstanbul, Tübitak Popüler Bilim Kitapları.

Henderson, P. (2002). Materials development in support of mathematical thinking. Retrieved from https://dl.acm.org/citation.cfm?id=783001

Hudson, B., Henderson, S., \& Hudson, A. (2015). Developing mathematical thinking in the primary classroom: Liberating students and teachers as learners of mathematics. Journal of Curriculum Studies, 47(3), 374-398. https://doi.org/10.1080/00220272.2014.979233

Mason, J., Burton, L., \& Stacey, K. (2010). Thinking Mathematically (2nd ed.). England: Pearson Education Limited.

MEB. (2018). Matematik Dersi Öğretim Programı (İlkokul ve Ortaokul 1, 2, 3, 4, 5, 6, 7 ve 8. Sinıflar). Retrieved from http://mufredat.meb.gov.tr/ProgramDetay.aspx?PID=329

Olkun, S., \& Toluk Uçar, Z. (2018). İlköğretimde etkinlik temelli matematik öğretimi (7. Basım). Nevşehir, Genç Kalemler Yayincilik.

Pesen, C. (2019). İlkokullarda Matematik Öğretimi (7. Bask1). Ankara, Pegem Akademi.

Sarı, M. H. (2014). Sınıf öğretmenlerine yönelik matematik öğretimi kaygı ölçeği geliştirme. İlköğretim Online, 13(4), 1296-1310. https://doi.org/10.17051/io.2014.11721

Sertöz, S. (2000). Matematiğin aydınlı dünyası (1. Basım). Ankara, Tübitak Popüler Bilim Kitapları.

Umay, U. (1992). Matematiksel düşünmede süreci ve sonucu yoklayan testler arasında bir karşılaştırma (Yayınlanmamış Doktora Tezi). Hacettepe Üniversitesi, Ankara.

Ural, A. (2015). The effect of mathematics self-efficacy on anxiety of teaching mathematics. Kuramsal Eğitimbilim Dergisi, 8(2), 173-184. https://doi.org/10.5578/keg.9075

Yıldırım, C. (1996). Matematiksel Düşünme. İstanbul, Remzi Kitabevi.

Yorulmaz, A., Altıntaş, S., \& Sidekli, S. (2017). Investigation of the effects of mathematical thinking states of form teachers on their mathematics teaching anxieties. European Journal of Educational Research, 6(4), 485-493. https://doi.org/10.12973/eu-jer.6.4.485

Yorulmaz, A., Çokçalışkan, H., \& Çelik, Ö. (2018). Sınıf öğretmeni adaylarının matematiksel düşünmeleri ile bireysel yenilikçilikleri arasındaki ilişkinin belirlenmesi. Trakya Üniversitesi Ë̆itim Fakültesi Dergisi, 8(2), 304-317. https://doi.org/10.24315/trkefd.321973 


\section{Copyrights}

Copyright for this article is retained by the author(s), with first publication rights granted to the journal.

This is an open-access article distributed under the terms and conditions of the Creative Commons Attribution license (http://creativecommons.org/licenses/by/4.0/). 